\title{
KONSEP PEMBAHARUAN PENDIDIKAN ISLAM MENURUT FAZLURRAHMAN
}

\author{
SAIHU \\ Institut PTIQ Jakarta \\ madesaihu@ptiq.ac.id
}

\begin{abstract}
ABSTRAK
Tulisan ini membahas tentang konsep pembaharuan pendidikan Islam menurut Fazlurrahman. Tulisan berfokus pada penelusuran pendekatan-pendekatan yang dilakukan oleh Fazlurrahman dalam memodernkan model pendidikan Islam sehingga relevan dengan situasi dan kondisi dimana model pendidikan itu diejewantahkan. Sumber data dalam tulisan ini diperoleh adalah melalui kajian pustaka buku-buku yang ditulis oleh Fazlurrahman dan undang-undang pendidikan atau undang-udang yang terkait dengan masalah pendidikan di Indonesia. Tulisan ini berupa penelitian kualitatif dengan menggunakan metode kajian pustaka (library research). Hasil dari tulisan ini memperlihatkan bahwa konsep pembaharuan pendidikan islam menurut Fazlurrahman, melibatkan 3 (tiga) pendekatan, yaitu: 1) Mengislamkan pendidikan sekuler modern; 2) Menyederhanakan silabus-silabus dalam rangka pendidikan tradisional; 3) Menggabungkan cabang-cabang ilmu pengetahuan. Melalui tiga pendekatan ini, fazlurrahman berargumen bahwa pendidikan Islam akan semakin berkembangan dan individu-individu (Muslim) dapat terhidar dari (split personality) atau pribadi-pribadi yang terpecah-pecah.
\end{abstract}

Kata Kunci: Pendidikan Islam, Pendekatan, Fazlurrahman, Split Personality

\begin{abstract}
This paper discusses the concept of renewal of Islamic education according to Fazlurrahman. The paper focuses on tracing the approaches taken by Fazlurrahman in modernizing the Islamic education model so that it is relevant to the situations and conditions in which the educational model is manifested. The source of the data in this paper was obtained through a literature review of books written by Fazlurrahman and the education or shrimp law relating to the problem of education in Indonesia. This paper is in the form of qualitative research using library research methods. The results of this paper show that the concept of renewal of Islamic education according to Fazlurrahman, involves 3 (three) approaches, namely: 1) Islamizing modern secular education; 2) Simplifying syllabi in the framework of traditional education; 3) Combining branches of science. Through these three approaches, Fazlurrahman argues that Islamic education will increasingly develop and individuals (Muslims) can be avoided from (split personality) or fragmented individuals.
\end{abstract}

Keywords: Islamic Education, Approach, Fazlurrahman, Split Personality 


\section{A. PENDAHULUAN}

Tulisan ini membahas tentang model pedidikan Islam modern dalam perspektif Fazlurrahman. Sebagaimana diketahui, Fazlurrahman adalah seorang pemikir kontemporer Islam yang banyak memiliki karya dan salah satunya adalah tentang pendidikan Islam. Hal ini penting untuk diuraikan, mengingat dan dewasa ini pendidikan Islam sedang mengalami kemuduran. Pemikiran pendidikan Islam Fazlurrahman dapat dijadikan landasan atau paling tidak rujukan dalam rangka mengembangkan pendidikan Islam di era kontemporer sekarang ini serta dapat bersaing dengan model pendidikan modern lainnya.

Sesungguhnya Islam sangatlah memperhatikan dan mementingkan pendidikan. Sebab pendidikan merupakan wadah untuk membentuk manusia yang sempurna. ${ }^{13}$ Selain itu dengan pendidikan yang baik dan berkualiatas, individu-individu yang beradab akan terbentuk dan pada akhirnya akan memunculkan kehidupan sosial yang bermoral. Pendidikan merupakan proses budaya untuk meningkatkan harkat dan martabat manusia yang berlangsung sepanjang hayat.

Pendidikan selalu berkembang dan selalu dihadapkan pada perubahan zaman. Untuk itu, mau tidak mau pendidikan harus didesain mengikuti irama perubahan tersebut. ${ }^{24}$ Akan tetapi dalam kenyataanya, pendidikan Islam masih menghadapi berbagai persoalan, baik yang bersifat teoritis konseptual maupun praktis. Di antara masalah teoretis konseptual yang paling memerlukan pemikiran lebih mendalam adalah persoalan epistemologi. Proses keilmuan di dalam Islam yang pada dasarnya telah banyak digariskan dari sumber al-Qur'an, masuk dalam kategori perennial knowledge telah banyak memberikan abstraksi tentang pola pendidikan Islam. ${ }^{3}$ Namun dalam perkembangannya, pemaknaan substansi alQur'an banyak diwarnai oleh logika manusia tanpa memandang aspek sejarah, sehingga terkadang kandungan murni dalam al-Qur'an mengalami distorsi. Dari distorsi semacam inilah, nilai minus keagamaan muncul dan mulai berkembang biak. Perjalanan waktu yang semacam ini sangat menuntut kepedulian semua umat Islam untuk berbenah diri. ${ }^{4}$

Persoalan yang kemudian muncul ke permukaan adalah klaim stagnasi pendidikan Islam. ${ }^{5}$ Stagnasi ini semakin membukakan mata mereka akan ketertinggalan dan kemundurannya di berbagai aspek kehidupan, terutama ilmu dan tekhnologi, kebudayaan, dan sistem pendidikan. Pendidikan Islam menurut 2011), 46 .

${ }^{1}$ Ahmad Tafsir, Ilmu Pendidikan Dalam Perspektif Islam (Bandung: PT. Remaja Rosdakarya,

2 H.A.R Tilar, Beberapa Agenda Reformasi Pendidikan Nasional Dalam Persepektif Abad 21 (Magelang: Tera Idonesia, 1998), 245.

3 Fazlur Rahman, Gelombang Perubahan Dalam Islam: Studi Tentang Fundamentalisme Islam (Jakarta: Rajawali Grafindo Persada, 2001), 34.

4 Fazlur Rahman, Islam dan Modernitas: Tentang Transformasi Intelektual (Bandung: Pustaka,1985), 38.

${ }^{5}$ Badri Yatim, Sejarah Peradaban Islam (Jakarta: Raja Grafindo Persada), 171. 
Fazrul Rahman bukan sekedar perlengkapan dan peralatan fisik atau kursi fisik pengjaran seperi buku- buku yang diajarkan. Dengan mendasar kepada al-Qur'an tujuan pendidikan adalah untuk mengembangkan manusia sedemikian rupa sehingga semua pengetahuan yang diperolehnya menjadi organ pada keseluruhan pribadi yang kreatif yang memungkinkan manusia untuk memanfaatkan sumber alam untuk kebaikan. Menurut Fazlur Rahman, meskipun telah dilakukan usahausaha pembaharuan pendidikan Islam, namun dunia pendidikan Islam masih tetap saja dihadapkan kepada beberapa problem, sehingga tujuan pendidikan Islam yang ada sekarang ini tidaklah benar-benar diarahkan kepada tujuan yang positif.

Tujuan pendidikan Islam hanya diorientasikan kepada kehidupan akhirat semata dan cenderung bersifat defendif, yaitu untuk menyelamatkan kaum muslimin dari pencemaran dan pengrusakan yang ditimbulkan oleh dampak gagasan barat yang datang melalui berbagai disiplin ilmu, terutama gagasangagasan yang mengancam akan meledakkan standar-standar moralitas tradisional Islam. ${ }^{6}$ Rahman, menyuguhkan analisis perkembangan pendidikan tinggi Islam dan merumuskan alternatif metodologi pemikiran keislaman, sebagai rumusan jalan keluar dari seluruh kritisisme atas sejarah pemikiran keislaman. Krisis metodologi tampaknya sangat disadari oleh Rahman sebagai penyebab kemunduran pemikiran Islam, karena alternatif metodologi dipandangnya sebagai titik pusat penyelesaian krisis Intelektualisme Islam.

Implikasi dari alternatif metodologis ini, menurutnya merupakan proyek besar ummat Islam yang mengarah pada pembaharuan pemikiran Islam. Rahman, menyadari bahwa proyek besar tersebut selain memerlukan waktu yang panjang juga memerlukan sarana penunjuang. Menurutnya sarana penunjuang yang dimaksud tiada lain adalah sistem pendidikan Islam. Sistem pendidikan harus terlebih dahulu dimodernisasi, membuatnya mampu menyokong produktivitas intelektual Islam dengan cara menaikkan standar-standar intelektualnya.

Kesadaran Rahman terhadap pendidikan sebagai sarana utama penunjang pembaharuan, mendorongnya terjun dalam kritisisme sistem pendidikan Islam yang berkembang pada periode kemunduran dan pada awal pembaharuan atau zaman modern menyusun sebuah karya umum yang secara historis mengemukan sistem pendidikan Islam pada abad pertengahan berikut kelebihan-kelebihan dan kekurangan- kekurangan utamanya, dan mengenai upaya- upaya modernisasi yang dilakukan sekitar abad yang lalu. Kemudian Rahman membangun suatu pemikiran pendidikan tinggi Islam yang disebut sebagai "intelektualisme Islam".

Stagnasi terjadi sampai awal periode modern barulah muncul suatu kesadaran umum di tengah umat Islam. Kebangkitan kembali umat Islam ini, salah satunya, sebagai reaksi terhadap fenomena penetratif dan hegemonitaskemajuan barat atas umat Islam (Islam dianggap tidak mampu menyelesaikan problema sosial yang terkait dengan kemunduran pendidikan. Oleh karenaya, semangat untuk maju juga patut ditanamkan dengan pandangan-pandangan historis. Islam mempunyai 
sejarah pendidikan yang ditapaki dari bentuk "pendidikan sederhana". Dalam kondisi kepanikan spiritual tersebut strategi pendidikan Islam yang dikembangkan secara umum di seluruh dunia Islam masih cenderung bersifat dikotomis, sehingga tidak bisa melahirkan umat Islam yang mempunyai komitmen spriritual dan intelektual yang mendalam terhadap Islam. $^{7}$

Di samping itu, upaya integrasi yang dilakukan pada umumnya belum membuahkan hasil. ${ }^{12}$ Hal ini dapat dianalisis dari pendekatan pembaharuan Pendidikan Islam yang telah dilakukan sejauh ini. Dari proses sejarah yang panjang, wajah Pendidikan Islam kini mulai nampak berdimensi. Hal ini dimaksudkan bahwa Islam mempunyailambang peta perjalanan pemikiran pendidikan yang berjalan silih berganti. Pendidikan Islam yang mengalami perubahan sesuai dengan perkembangan zaman, perkembangan ilmu pengetahuan serta perkembangan teknologi. Dalam perkembangan tersebut lebih lanjut menyentuh berbagai aspek pendidikan (Pendidikan Islam) yang ada. ${ }^{8}$ Oleh sebab itu, mau tidak mau Pendidikan Islam harus didesain mengikuti perubahan perkembangan zaman, kalau tidak begitu maka siap-siap pendidikan Islam akan ketinggalan.

Salah satunya adalah tawaran ide Fazlur Rahman tentang model pendidikan Islam melalui kurikulumnya mengarah pada pembentukan pendidikan berkarakter Islami dan integrasi ilmu, (walaupun istilah ini tidakdiungkapkan oleh Fazlur Rahman) namun dapat dilihat dari pola pikir Fazlur Rahman tentang Neomodernisme. (upaya sintesis antara pola pemikiran tradisionalisme dan modernisme). ${ }^{915}$ Tawaran tersebut senada dengan Pendidikan Islam yang mengikuti zaman. Melalui kajiannya terhadap berbagai literatur klasik Fazlur Rahman memperkenalkan gagasan dan pemikirannya tentang pembaruan pendidikan. Menurutnya, bahwa pembaruan pendidikan Islam dapat dilakukan dengan menerima pendidikan sekuler moderen, kemudian berusaha memasukinya dengan konsep-konsep Islam. Upaya pembaruan pendidikan Islam ini menurutnya dapat di tempuh dengan cara. Membangkitkan idiologi umat Islam tentang pentingnya belajar dan mengembangkan ilmu pengetahuan, Berusaha mengikis dualisme sistem pendidikan umat Islam.

Pada satu sisi ada pendidikan tradisional (agama), dan pada sisi lain, ada pendidikan moderen (sekuler). Karena itu, perlu ada upaya mengintegrasikan antara keduanya. Menyadari betapa pentingnya bahasa dalam pendidikan dan sebagai alat untuk mengeluarkan pendapat-pendapat yang orisinil. Bahkan ia katakan, bahawa umat Islam adalah masyarakat tanpa bahasa. Pembaruan di bidang metode pendidikan Islam, yaitu beralih dari metode mengulang-ngulang (membeo) dan menghafal pelajaran kemetode memahami dan menganalisis.

7 Ahmad Syafi'i Ma'arif, Peta Bumi Intelektualisme Islam Di Indonesia (Bandung: Mizan, 1993), 146.

${ }^{8}$ Hasan Basri, Metode Pendidikan Islam Muhammad Qutb (Kediri: Stain Kediri Press, 2009), 115.

${ }^{9}$ Fazlur Rahman, "The Qur"Anic Solution Of Pakistan Educational Problem", IslamicStudies, Vol. 6, No. 4, (1967), 143. 
Fazrul Rahman berbicara tentang berbagai aspek fundamental tentang pendidikan, antara lain tentang dasar pemikiran pendidikan islam, corak dan bentuk pendidikan islam, termasuk strategi pendidikan Islam termasuk strategi pendidikan Islam sekarang menurut Fazlur Rahman cenderung bersifat defensif, yaitu hanya menyelamatkan pikiran kaum muslimin dari pencemaran dan kesusahan yang di timbulkan oleh dampak gagasan-gagasan barat yang datang melalui berbagai disiplin Ilmu, terutama gagasan-gagasan yang akan mengancam.

\section{B. METODE}

Metode yang digunakan dalam penelitian ini adalah kualitatif. Menurut Nana Syaodih Sukmadinata, penelitian kualitatif adalah suatu penelitian yang ditujukan untuk mendeskripsikan dan menganalisa fenomena peristiwa, aktivitas sosial, sikap, kepercayaan, persepsi, pemikiran orang secara individual maupun kelompok. Penelitian ini menggunakan pendekatan metode deskriptif. Metode deskriptif menurut Best, "metode deskriptif merupakan metode penelitian yang berusaha menggambarkan dan menginterpretasi objek sesuai dengan apa adanya. Data yang dikumpulkan adalah berupa kata-kata, gambar dan bukan angka-angka. Penelitian deskriptif pada umumnya dilakukan dengan tujuan utama, yaitu menggambarkan secara sistematis fakta dan karakteristik objek atau subjek yang diteliti secara tepat.

Jenis penelitian ini adalah penelitian kepustakaan (library research) maka dari itu diperlukan banyaknya literatur-literatur yang relevan dengan konten kebebasan manusia dalam berkreativitas ditinjau pendidikan Islam. Untuk memudahkan pengumpulan data, fakta dan informasi yang mengungkapkan dan menjelaskan permasalahan dalam penelitian ini, penulis menggunakan metode penelitian studi kepustakaan, yaitu mengumpulkan data, fakta dan informasi berupa tulisan-tulisan dengan bantuan bermacammacam material yang terdapat di ruangan perpustakaan untuk mencari pijakan atau fondasi landasan teori, misalnya berupa jurnal, buku-buku yang relevan, majalah, naskah, catatan kisah sejarah; surat kabar, internet dan sumber lain yang berhubungan dengan penelitian ini. Sumber data pokok yang akan diteliti dalam penelitian ini berupa buku-buku yang berhubungan dengan masalah yang diteliti. Literature yang terdiri dari: Pertama, sumber data utama (Primer), yaitu: buku-buku yang mengacu kepada pokok bahasan terutama pemikiran tokoh Fazlur Rahman; Kedua, sumber data Skunder yang merupakan buku-buku penunjang ataupun pembanding terhadap judul yang akan diteliti.

Pengecekan Keabsahan Data Pengecekan keabsahan data dalam penelitian ini dilakukan dengan empat cara, yaitu:

1. Kredibilitas

Data Kriteria kredibilitas melibatkan penetapan hasil penelitian kualitatif adalah kredibel atau dapat dipercaya dari perspektif partisipan dalam penelitian tersebut. Strateginya meliputi perpanjangan pengamatan, ketekunan penelitian, triangulasi (mengecek keabsahan data dengan memanfaatkan berbagai sumber dari luar data sebagi bahan perbandingan), diskusi teman sejawat, analisis kasus 
negatif dan membercheking.

2. Transferabilitas

Dilakukan dengan cara memberikan kesempatan kepada semua orang untuk membaca laporan penelitian sementara yang telah dihasilkan oleh peneliti, kemudian pembaca diminta untuk menilai substansi penelitian tersebut dalam kaitannya dengan fokus penelitian. Peneliti dapat meningkatkan transferabilitas dengan melakukan suatu pekerjaan mendeskripsikan konteks penelitian dan asumsi yang menjadi sentral pada penelitian tersebut. Dengan kata lain apakah hasil penelitian ini dapat diterapkan pada situasi yang lain.

3. Dependabilitas

Data Apakah hasil penelitian mengacu pada kekonsistenan peneliti dalam mengumpulkan data, membentuk, dan menggunakan konsepkonsep ketika membuat interpretasi untuk menarik kesimpulan. Artinya apakah peneliti akan memperoleh hasil yang sama jika peneliti melakukan pengamatan yang sama untuk kedua kalinya.

4. Konfirmabilitas

Yaitu apakah hasil penelitian dapat dibuktikan kebenarannya dimana hasil penelitian sesuai dengan data yang dikumpulkan dan dicantumkan dalam laporan lapangan. Hal ini dilakukan dengan membicarakan hasil penelitian dengan orang yang tidak ikut dan tidak.

Selanjutnya analisis data penelitian kualitatif bersifat interaktif, berlangsung dalam lingkaran yang saling tumpang tindih. Teknik yang digunakan fleksibel, tergantung pada strategi terdahulu yang digunakan dan data yang telah diperoleh. Secara umum langkah-langkahnya ada kesamaan antara satu penelitian dengan penelitian lainya, tetapi di dalamnya ada variasi. Dalam menganalisis data yang telah berkumpul menggunakan teknik deskriptif analitik, yaitu teknik analisa data yang menggunakan, menafsirkan serta mengklasifikasikan dengan membandingkan fenomena-fenomena pada masalah yang diteliti melalui langkah pengumpulan data, menganalisa data, menginterpretasi data dengan cara berfikir: a) Deduktif, yaitu teknik berpikir yang berangkat dari pengetahuan yang sifatnya umum, dan bertitik tolak pada pengetahuan yang umum itu lalu hendak menilai suatu kejadian yang bersifat khusus; b) Induktif, yaitu: berpikir dengan menelaah dari fakta-fakta yang khusus, peristiwa-peristiwa yang konkrit, kemudian dari fakta- fakta atau peristiwa yang khusus konkret itu ditarik generalisasi-generalisasi yang bersifat umum.

\section{HASIL DAN PEMBAHASAN}

Kata pendidikan terambil dari kata education dan education berasal dari kata educe yang berari member peningkatan (to elicit, to give rise to), dan mengembangkan ( to evolve, to develop). Namun, education dalam pengertian yang sempit berarti perbuatan atau proses perbuatan untuk memperoleh pengetahuan. ${ }^{10}$ Sementara

${ }^{10}$ Islamuddin Haryu, Psikologi Pendidikan (Yogyakarta : Pustaka Pelajar, 2012), 3-4. 
dalam bahasa yunani, kata pendidikan dikenal dengan nama "paedagogos" yang berarti penuntun anak dan dalam bahasa Romawi, dikenal dengan "educare", artinya membawa keluar (sesuatu yang ada di dalam), begitu juga dalam bahasa Belanda menyebut pendidikan dengan nama "opvoeden", yang berarti membesarkan atau mendewasakan, atau "voden" artinya memberi makan. ${ }^{11}$ Ilmu Pendidikan menurut Islam adalah suatu konsep, ide, nilai dan norma-norma kependidikan yang diambil, dipahami dan dianalisis lalu dimunculkan dari sumber pokok ajran agama islam (AlQur'an dan Hadits). Perspektif ini bersifat filosofis karena menganalisis langsung dari sumber pokok ajaran isla, sehingga kemudian melahirkan suatu ilmu yang dikenal dengan istilah Filsafat Pendidikan Islam. Ilmu Pendidikan dalam islam, adalah suatu ilmu yang membicarakan tentang prosespembudidayaan dan pewarisan pengalaman dan nilai-nilai ajaran Islam yang berlangsung sepanjang sejarah islam, sejak zaman Nabi sampai sekarang. ${ }^{12}$

Dalam pengembangan istilah Pendidikan berarti bimbingan atau pertolongan yang diberikan dengan sengaja terhadap anak didik oleh orang dewasa agar ia menjadi dewasa. Dalam perkembangan selanjutnya, pendidikan berarti usaha yang di jalankan oleh seseorang atau sekelompok orang untuk mempengaruhi seseorang agar menjadi dewasa atau mencapai tingkat hidup dan penghidupan yang lebih tinggi (mental). Dengan demikian pendidikan berarti segala usaha orang dewasa dalam pergaulan dengan anak-anak untuk memimpin perkembangan jasmani dan rohaninya kearah kedewasaan. ${ }^{13}$

Secara specifik, Pendidikan Islam (tarbiyah al-islamiyah), sering diartikan sebagai proses pemeliharaan, pengembangan dan pembinaan. Dalam tradisi islam di jumpai pula istilah ta'lim yang sering di artikan sebgai pengajaran. Yusuf Faisal mengartikan pendidikan secara etimologi, bahwa kata Tarbiyah dan kata Ta'lim, masing masing berasal dari kata "Rabba" dan "Allama" yang berarti: memelihara, membesarkan dan mendidik. Selain itu terdapat pula istilah "ta'dib" yang ada hubunganya dengan kata adab yang berarti "susunan". ${ }^{14}$ Sementara menurut Fuad 'Abd al-Baqy dalam bukunya "al-mu'jam al-mufahras li alfadz al- qur'an al-karim', bahwa di dalam Al-Qur'an kata tarbiyah dengan berbagai kata yang serumpun dengannya diulang sebanyak lebih dari 872 kali. Kata tersebut sebagaimana dijelaskan oleh al-Raghib al- Ashfahany, bahwa pada mulanya tarbiyah itu digunakan dalam arti "insya' al-sya'ihalan fa halun ila hadad al-tamam," yang artinya mengembangkan atau menumbuhkan sesuatu setahap demi tahapa sampai pada batas yang sempuurna. ${ }^{15}$

Ilmu Pendidikan Islami adalah ilmu Pendidikan yang berdasarkan Islam.

\footnotetext{
${ }^{11}$ Islamuddin Haryu, Psikologi Pendidikan, 35.

12 Fatah Yasin, Dimensi-dimensi Pendidikan Islam (UIN-Malang Press, 2008), 3.

${ }^{13}$ Ramayulis, Filsafat pendidikan: telaah sistem pendidikan dan pemikiran para tokohnya (Jakarat: Kalam mulia,2009), 83.

${ }^{14}$ Lihat Ali ansar, Bahan Ajar Pedagogik (Padang: Universitas Negeri Padang, 2008), 67.

${ }^{15}$ Irsjad Djuwaeli, Pembaharuan Kembali Pendidikan Islam (Ciputat: Karsa Utama Mandiri dan PB Mathala'ul Anwar, 1998), 3.
} 
Islam adalah nama Agama yang dibawa Nabi Muhammad SAW. Islam berisi seperangkat ajaran tentang kehidupan manusia ajaran itu dirumuskan berdasarkan dan berusmber dari Al- Qur'an dan hadits serta akal. Jika demikian, maka ilmu pendidikan Islam adalah ilmu pendidikan yang berdasarkan Al-Qur'an, hadits, dan akal penggunaan dasar ini haruslah berurutan, Al-Qur'an terlebih dahulu bila tidak ada atau tidak jelas lihat didalam hadits, bila tidak ada barulah digunakan akal (pemikiran), tetapi temuan akal itu tidak boleh bertentangan dengan jiwa Al-Qur'an dan atau hadits, oleh karena itu teori dalam pendidikan Islam haruslah dilengkapi dengan ayat-ayat Al-Qur'an dan atau Hadits dan atau argument (akal yang menjamin teori tersebut). Jadi pembuatan dan penulisan teori dalam Ilmu pendidikan Islami tidak jauh berbeda dari pembuatan dan penulisan teori dalam Fiqih. ${ }^{16}$

Alasan mengapa ilmu pendidikan islam sangat diperlukan, antara lain : 1) Pendidikan sebagai usaha membentuk pribadi manusia harus melalui proses yang panjang, dengan hasil yang tidak dapat diketahui dengan segera. Dalam proses pembentukan tersebut diperlukan suatu perhitungan yang matang dan hati-hati berdasarkan pandangan dan pemikiran-pemikiran atau teori yang cepat, sehingga keggalan atau kesalahan langakah pembentukan terhadap anak didik dapat dihindarkan; 2) Pendidikan Islam yang bersumber dari nilai-nilai ajaran Islam harus bisa menanamkan atau membentuk sikap hidup yang dijiwai nilai-nilai tersebut, juga mengembangkan kemapuan berilmu pengetahuan sejalan dengan nilai-nilai islam yang melandasi, merupakan proses ikhtiariah yang secara pedagogis mamapu mengembangkan hidup anak ke arah kedewasaan atau kematangan yang menguntungkan dirinya. ${ }^{17}$

Secara umum, tujuan pendidikan Islam adalah untuk mencapai tujuan hidup muslim, yakni menumbuhkan kesadaran manusia sebagai makluk Allah SWT agar mereka tumbuh dan berkembang menjadi manusia yang berakhalak mulia dari beribadah kepada-Nya. ${ }^{18}$ Lebih dalam lagi, Abudin Nata, menjelaskan, bahwa tujuan pendidikan Islam, yaitu: 1) Mengarahkan manusia agar menjadi Khalifah tuhan di Muka bumi dengan sebaik-baiknya, yakni melaksanakan tugas-tugas memakmurkan dan mengolah bumi sesuai kehendak Tuhan; 2) Mengarahkan manusia agar seluruh pelaksaaan tugas Kekhalifahannya di muka bumi filaksanakan dalam rangka beribadah kepada Allah, sehingga tugas tersebut terasa ringan dilaksanakan; 3) Mengarahkan agar manusia berkahalak mulia, sehingga ia tak menyalahgunakan fungsi kekhalifahnnya; 4) Membina dan mengrahkan potensi kala, jiwa dan jasmaninya, sehingga ia memiliki ilmu, akhalak dan keterampilan semua ini dapat digunakan guna mendukung tugas pengabdian dan kekhalifahannya; 5) Mengarahkan manusia agar dapat mencapai kebahagiaan hidup di dunia akhirat. ${ }^{19}$

Al-Qur'an merekognisi tujuan pendidikan Islam dalam beberapa ayat:

\footnotetext{
${ }^{16}$ Ahmad Tafsir, Ilmu pendidikan Islam ( Bandung : PT Remaja Rosdakarya, 2013), 18.

${ }_{17}$ M. Arifin, Ilmu Pendidikan Islam ( Jakarta : PT Bumi Aksara, 2008), 9.

18 Abuddin Nata, Kapita Selekta Pendidikan Islam (Bandung: Angkasa Bandung,2003), 211.

${ }^{19}$ Abuddin Nata, Filsafat Pendidikan Islam, cet 1, (Jakarta: Logos Wacana Ilmu, 1997), 53-55.
} 
a) Tujuan pertama adalah menumbuhkan dan mengembangkan ketaqwaan kepada Allah SWT sebaagai firman Allah SWT QS. Ali-Imran ayat 102.

b) Tujuan Pendidikan Islam adalah memudahkan sikap dan jiwa yang selalu beribadah kepada Allah, sebagaimana firman-Nya QS. Az-Zariyat ayat 56.

c) Tujuan Pendidikan Islam adalah membina dan memupuk akhalakul karimah sebagai Firman Allah, sebagai firman-Nya dalam QS. Al-Ahzab ayat 33.

Dengan demikian, tujuan Pendidikan Islam adalah untuk menumbuhkan kesadaran manusia agar menjadi manusia yanng berkakhalak mulia dan beribadah hanya kepada Allah SWR sebagai perwujudan akan tugas menjadi kahalifah di muka bumi guna mencapai kebahagiaan di dunia dan akhirat. ${ }^{20}$

Selanjutnya, karakteristik pendidikan Islam dapat dilihat pada dua sisi: 1) Aspek-aspek fundemental yang menggambarkan dasar dan tujuan pendidikan sehingga membedakannya dengan pendidikan non Islam; 2) Kandugan utama pendidikan Islam yang menjadi subsitansi untuk dikembangkan dalam kurikulumnya. Karakter pendidikan islam, antara lain: 1) Menekankan pada pencarian Ilmu pengetahuan, penguasaan dan pengembangan atas dasar ibadah keada Allah SWT; 2) Menekankan niali-nilai akhlak, pengakuan akan potensi dan kemapuan seseorang untuk berkembang dalam suaru kepribadian, dan pengalaman ilmu pengetahuan atas dasar tanggung jawab kepada tuhan dan masyarakat manusia. ${ }^{21}$ Namun luhurnya nilai, tujuan, dan karakter pendidikan Islam ini ternyata masih belum mampu menjawab problematikan umat Islam di era kontemporer sekarang ini. Maka dari itu dibutuhkan pembaharuan agar epistemologi pendidikan Islam sejalan dengan perkembangan zaman.

Salah satunya pendekatan untuk suatu penyelesaian jangka panjang atas permasalahan yang dialami masyarakat Islam ini adalah perlunya strategi dengan memasukkan konsep-konsep kunci tertentu mengenai Islam. Strategi ini melibatkan dua aspek yang saling berhubungan, diantaranya adalah membentuk mental anak didik dengan nilai-nilai Islam terhadap kepentingan kehidupan pribadi dan kolektif, kemudian memasukkan nilai-nilai Islam ke dalam bidang-bidang studi yang lebih tinggi. Ada tiga pendekatan pembaharuan pendidikan yang ia lakukan pada waktu itu yakni: mengislamkan pendidikan sekuler modern, menyederhanakan silabussilabus dalam rangka pendidikan tradisional, menggabungkan cabang-cabang ilmu pengetahuan.

Tujuan pendidikan menurut Fazlur Rahman ada tiga, yaitu: a) Untuk mengembangkan manusia sedemikian rupa sehingga semua pengetahuan yang

${ }^{20}$ Ada 5 (lima) asas pendidikan Islam yang banyak diuraikan dalam al-Qur'an, yaitu: a) Asas pendidikan tauhid; b) Asas Pendidikan akhalaq kepada orang tua dan masyarakat; c) Asas pendidikan amar ma'ruf nahi munkar; d) Asas pendidikan kesabaran dan ketabahan; e) Azas Pendidikan sosial kemasyarakatan (tidak boleh sombong). Munardji, Ilmu Pendidikan Islam (Jakarta, PT Bina Ilmu, 2004), 48.

${ }^{21}$ Saihu, "Pendidikan Sosial yang Terkandung dalam Surat At-Taubah Ayat 71-72", Edukasi Islami: Jurnal Pendidikan Islam, VOL: 09. No: 01 (2020): 127-148. 
diperolehnya akan menjadi organ pada keseluruhan pribadi yang kreatif; b) Menyelamatkan manusia dari diri sendiri, oleh diri sendiri, dan untuk diri sendiri. Pendidikan adalah bekal terbaik untuk perkembangan setiap individu; c) Untuk melahirkan ilmuwan yang padanya terintegrasi ilmu- ilmu agama dan ilmu-ilmu umum modern yang ditandai oleh adanya sifat kritis dan kreatif .

Selain itu, Fazlur Rahman menyatakan dengan tegas bahwa tujuan pendidikan Islam adalah untuk menanamkan komitmen-komitmen nilai melalui tarbiyah (pendidikan moral) dan mengkomunikasikan pengetahuan ilmiah melalui Ta'lim (pengajaran). Undang-Undang Nomor 20 Tahun 2003 tentang Sisdiknas menyatakan bahwa, "Pendidikan nasional bertujuan untuk mengembangkan potensi peserta didik agar menjadi manusia yang beriman dan bertakwa kepada Tuhan Yang Maha Esa, berakhlak mulia, sehat, berilmu, cakap, kreatif, mandiri, dan menjadi warga negara yang demokratis serta bertanggung jawab." Uraian ini juga sejalan dengan tujuan pendidikan Islam menurut Fazlur Rahman.

Pendidikan sesungguhnya, senantiasa mengarahkan individu menjadi pribadi yang berwawasan iman dan takwa (imtaq) serta seimbang baik dari segi afektif, kognitif, maupun psikomotoriknya. Salah satu cara mewujudkan tujuan tersebut adalah dengan pemberian materi agama dan ilmu-ilmu umum. Selain itu, pendidikan juga bertujuan untuk menghasilkan manusia yang kreatif dan kritis. Untuk mewujudkan sifat kritis, proses pembelajaran hendaknya berpusat pada peserta didik, karena setiap peserta didik memiliki perbedaan minat (interest), kemampuan (ability), kesenangan (preference), pengalaman (experience) dan cara belajar (learning style). Kegiatan pembelajaran perlu menempatkan peserta didik sebagai subjek belajar dan mendorong peserta didik untuk mengembangkan segenap bakat dan potensinya secara optimal. Adapun untuk mengembangkan sifat kritis peserta didik, diperlukan kemampuan dalam menganalisis pengetahuan kritis. Pengetahuan kritis adalah pengetahuan yang diyakini sebagai katalisator dan mobilisator yang mampu membebaskan manusia dari segenap ketidakadilan dan problematika sosial.

Terkait dengan masalah pendidikan dapat disimpulkan bahwa keadaan peserta didik saat ini mengalami permasalahan serius akibat adanya dikotomi, sehingga muncul pribadi yang terpecah-pecah (split personality). Padahal bagi Rahman, ilmu pengetahuan itu pada prinsipnya adalah satu, yaitu berasal dari Allah Swt. (Rahman, Untuk mengatasi hal tersebut, Rahman memiliki alternatif dengan memberikan materi pelajaran secara historis, kritis, dan holistik .

Pemberian materi secara historis, kritis, dan holistik sesuai dengan pembelajaran Kurikulum 2013 yang bersifat tematik terpadu. "Pembelajaran Tematik Terpadu dilaksanakan dengan menggunakan prinsip pembelajaran terpadu. Pembelajaran terpadu menggunakan tema sebagai pemersatu kegiatan pembelajaran yang memadukan beberapa mata pelajaran sekaligus dalam satu kali tatap muka, untuk memberikan pengalaman yang bermakna bagi peserta didik. Karena peserta didik dalam memahami berbagai konsep yang mereka pelajari selalu 
melalui pengalaman langsung dan menghubungkannya dengan konsep lain yang telah dikuasainya."

Pembelajaran tematik terpadu dalam Kurikulum 2013 untuk SD/MI merupakan langkah serius yang diterapkan oleh pemerintah dalam upaya meningkatkan kualitas peserta didik serta menghindarkan munculnya split personality seperti yang dikemukakan Fazlur Rahman. Adapun pelaksanaan pembelajaran tematik dijelaskan dalam paragraf berikut "Pelaksanaan pembelajaran Tematik Terpadu berawal dari tema yang telah dipilih/dikembangkan oleh guru yang sesuai dengan kebutuhan peserta didik.

Jika dibandingkan dengan pembelajaran konvensional pembelajaran tematik ini tampak lebih menekankan pada Tema sebagai pemersatu berbagai mata pelajaran yang lebih diutamakan pada makna belajar, dan keterkaitan berbagai konsep mata pelajaran. Keterlibatan peserta didik dalam belajar lebih diprioritaskan dan pembelajaran yang bertujuan mengaktifkan peserta didik, memberikan pengalaman langsung serta tidak tampak adanya pemisahan antar mata pelajaran satu dengan lainnya." Untuk menerapkan pembelajaran ini, tentu diperlukan pendidik yang benar-benar menguasai bidang keilmuan secara kritis dan komperehensif.

Pendidik dalam Islam dimaknai sebagai orang-orang yang bertanggung jawab terhadap perkembangan anak didik dengan mengupayakan perkembangan seluruh potensi anak didik, baik potensi afektif, kognitif, maupun psikomotorik. Sayangnya, menurut Rahman, pendidik yang berkualitas sangat sulit ditemukan di lembaga-lembaga pendidikan. ${ }^{22}$ Untuk mengatasi kelangkaan tenaga pendidik seperti itu, Rahman menawarkan beberapa mengenai pendidikan diantaranya adalah gagasan sebagai berikut: a) Merekrut dan mempersiapkan anak didik yang memiliki bakat- bakat terbaik dan mempunyai komitmen tinggi terhadap lapangan agama Islam; b) Meningkatkan lulusan madrasah yang relatif cerdas atau menunjuk para doktor lulusan Barat menjadi guru besar pada bidang studi Bahasa Arab, Bahasa Persi, dan Sejarah Islam; c) Para pendidik harus dilatih di pusat pusat studi Islam di luar negeri, khususnya Barat. Hal ini pernah dilakukan Rahman sewaktu ia menjabat direktur Institut Pusat Penelitian Islam di Pakistan; d) Melatih lulusan madrasah yang memiliki kemampuan bahasa Arab dengan riset modern serta menarik lulusan bidang filsafat dan ilmuilmu sosial untuk dilatih bahasa Arab dan disiplin Islam klasik; e) Menggiatkan para pendidik untuk melahirkan karya-karya keislaman secara kreatif dan memiliki tujuan.

Sejalan dengan yang dikemukakan Fazlur Rahman, UndangUndang No. 14 Tahun 2005 mendefinisikan bahwa guru adalah pendidik profesional dengan tugas utama mendidik, mengajar, membimbing, mengarahkan, melatih, menilai, dan mengevaluasi peserta didik pada pendidikan anak usia dini jalur pendidikan formal, pendidikan dasar, dan pendidikan menengah. Berdasarkan definisi di atas, dapat disimpulkan bahwa seorang pendidik memiliki tugas utama mendidik, 
mengajar, membimbing, mengarahkan, melatih, menilai hingga melakukan evaluasi peserta didik.

Seorang pendidik tidak hanya mentransfer ilmu pengetahuan saja, tetapi juga mentransfer nilai-nilai, etika dan moral yang baik. Sebagai seorang murabbi ruh, pendidik juga bertugas melakukan bimbingan dan pelatihan, baik dalam kegiatan kelas maupun kegiatan di luar kelas. Pendidik harus siap mendengarkan permasalahan yang dialami peserta didik serta menawarkan berbagai solusi untuk menyelesaikannya. Pendidik juga harus mengarahkan peserta didik untuk mengembangkan minat dan bakatnya. Selain itu, pendidik harus melakukan penilaian dan evaluasi untuk melihat kemajuan yang dialami oleh peserta didik. Oleh karena itu, seorang guru dituntut memiliki kompetensi pedagogik, sosial, kepribadian, profesional, dan leadership. Berdasarkan uraian tersebut, dapat kitadefinisikan kembali bahwa secara umum, pendidik merupakan orang yang memiliki tanggung jawab terhadap perkembangan peserta didik, baik perkembangan dalam aspekkognitif, afektif, maupun psikomotorik.

Definisi pendidik menurut Fazlur Rahman juga senada dengan definisi pendidik dalam buku "Ilmu Pendidikan Islam" yang ditulis oleh Muhammad Muntahibun Nafis. Buku tersebut menjelaskan bahwa pendidik dalam pendidikan Islam pada hakikatnya adalah orang-orang yang bertanggung jawab terhadap perkembangan peserta didik dengan mengupayakan seluruh potensi dan kecenderungan yang ada pada peserta didik, baik yang mencakup ranah afektif, kognitif, maupun psikomotorik, sehingga kemudian ditemukan bahwa ada relevansi antara pemikiran Fazlur Rahman dengan konsep pendidik untuk saat ini.

Seperti yang diungkapkan Fazlur Rahman, pendidik dengan kriteria seperti itu tidak banyak ditemukan di lapangan karena pada praktiknya kita sering menjumpai pendidik yang tidak memenuhi kualifikasi dan kompetensi yang ditentukan. Menanggapi hal tersebut, sebenarnya pemerintah telah mengeluarkan peraturan dan kebijakan melalui undang-undang, di antaranya dalam UU No. 14 Tahun 2005 Tentang Guru dan Dosen Pasal 34 Ayat 1 yaitu "Pemerintah dan pemerintah daerah wajib membina dan mengembangkan kualifikasi akademik dan kompetensi guru pada satuan pendidikan yang diselenggarakan oleh Pemerintah, pemerintah daerah, dan/atau masyarakat."

Salah satu langkah yang ditempuh oleh pemerintah untuk mengembangkan kualifikasi akademik dan kompetensi guru adalah sertifikasi. Sertifikasi merupakan proses pemberian sertifikat untuk pendidik. Sertifikat diperoleh melalui beberapa syarat tertentu. Selain itu, pendidik juga digiatkan untuk membuat berbagai tulisan serta melakukan riset dengan menerbitkan jurnal, mengingat negara kita cukup tertinggal dalam masalah ini.

Pendidik atau calon pendidik yang berprestasi juga diberi kesempatan melanjutkan studinya dengan beasiswa. Adapun terkait pelatihan, pendidik diperkenankan mengikuti berbagai pelatihan dan seminar, seperti pelatihan Kurikulum 2013 dan lain-lain. Dengan demikian, usaha Fazlur Rahman dalam 
upaya peningkatan kualitas pendidik relevan dengan usaha yang dilakukan pemerintah. Justru usaha Rahman dapat dijadikan sebagai model yang nantinya dapat diterapkan oleh pemerintah Indonesia untuk semakin meningkatkan kualitas pendidik secara lebih komperehensif.

Proses pembelajaran pada Kurikulum 2013 tidak lagi berpusat pada guru, tetapi berpusat pada siswa. Hal ini bukan berarti guru tidak memiliki peran. Guru menjadi fasilitator yang bertugas mengatur jalannya pembelajaran di kelas, sehingga baik guru maupun siswa sama-sama memiliki peran aktif dalam menciptakan pembelajaran yang menyenangkan. Guru tidak melulu menyampaikan materi dengan metode ceramah, tetapi juga dengan diskusi, tanya jawab, dan sebagainya. Bahkan masih ada puluhan strategi yang bisa diterapkan. Selain itu, proses pembelajaran yang pada mulanya berupa eksplorasi, elaborasi, dan konfirmasi (EEK), pada Kurikulum 2013 ini dikembangkan menjadi mengamati, menanya, mencoba, menalar, dan menyajikan (5M). Di sini, metode double movement Fazlur Rahman relevan dengan metode yang diterapkan dalam Kurikulum 2013.

Pendidikan di Indonesia menyelenggarakan pembelajaran bahasa Inggris dan bahasa Arab serta melengkapi literatur di perpustakaan dengan kedua bahasa tersebut. Pentingnya kedua bahasa tersebut menjadikan lembaga pendidikan non formal turut menyelenggarakan pembelajaran bahasa asing untuk menunjang kemampuan bahasa peserta didik. Bahkan pesantren sebagai lembaga pendidikan Islam juga telah banyak yang memfokuskan kajian terhadap kedua bahasa tersebut. Literatur atau buku-buku yang menggunakan bahasa Inggris dan Arab pada pendidikan formal dapat kita jumpai di level terbawah, seperti PAUD dan TK. Ketersediaan bukubuku tersebut masih berlanjut hingga perguruan tinggi. Dengan demikian, pemikiran Fazlur Rahman mengenai sarana pendidikan memiliki relevansi dengan sarana pendidikan di Indonesia yang sama-sama masih menunjukkan adanya kekurangan sehingga diperlukan adanya tambahan.

\section{D.KESIMPULAN}

Fazlurrahman, menawarkan 3 (tiga) pendekatan pembaharuan pendidikan, yaitu: 1) Mengislamkan pendidikan sekuler modern; 2) Menyederhanakan silabussilabus dalam rangka pendidikan tradisional; 3) Menggabungkan cabang-cabang ilmu pengetahuan. Dengan demikian, maka tujuan pendidikan Islam akan mengarah pada: a) Pengembangan manusia sedemikian rupa sehingga semua pengetahuan yang diperolehnya akan menjadi organ pada keseluruhan pribadi yang kreatif; b) Menyelamatkan manusia dari diri sendiri, oleh diri sendiri, dan untuk diri sendiri. Dan c) Untuk melahirkan ilmuwan yang padanya terintegrasi ilmu- ilmu agama dan ilmu-ilmu umum modern yang ditandai oleh adanya sifat kritis dan kreatif .

Selain itu, Fazlur Rahman menyatakan dengan tegas bahwa tujuan pendidikan Islam adalah untuk menanamkan komitmen-komitmen nilai melalui tarbiyah (pendidikan moral) dan mengkomunikasikan pengetahuan ilmiah melalui Ta'lim (pengajaran), memasukkan nilai-nilai agama dalam materi-materi ilmu-ilmu 
umum, sehingga tidak terjadi dikotomi keilmuan yang mengarah pada pribadi yang terpecah-pecah (split personality). Pemikiran Fazlur Rahman ternyata relevan dengan pendidikan di Indonesia dilihat dari dasar pendidikan, pengertian pendidikan Islam, tujuan pendidikan, peserta didik, pendidik, metode pendidikan Islam, dan sarana pendidikan. Selanjutnya, penulis memberikan saran keada pembaca baik sebagai stake holder pendidikan atau pendidik, yaitu agar: a) Dalam mengelola dunia pendidikan, harus banyak memasukkan pemikiran tokoh-tokoh pendidikan islam; b) Menfilter materi-materi pendidikan yang tidak sesuai dengan budaya bangsa dan yang memiliki pengaruh negatif bagi pengembangan umat Islam dan lembagalembaga pendidikan Islam. 


\section{DAFTAR PUSTAKA}

Abd al- Ghani 'Abud, Dirasat Muqaranat li Tarikh al - Tarbiyah, Kairo : Dar al- Fikr alArabi, 1986

Abdullah Al-Qari bn Haji Salleh, Dasar-Dasar Pendidikan Menurut Islam, Klantan: Pustaka Aman press SDN, 1972.

Aliansar, dkk., Bahan Ajar Pedagogik. Padang : Universitas Negeri Padang, 2008.

Ahmad Tafsir, Ilmu Pendidikan Dalam Perspektif Islam, Bandung: PT. Remaja Rosdakarya, 2011.

Ahmad Syafi'I Ma'Arif, Peta Bumi Intelektualisme Islam Di Indonesia, Bandung: Mizan, 1993.

Amir Feisal Yusuf, Reorientasi Pendidikan Islam, Jakarta : Geman Insani Press, 1995.

Arifin M, Ilmu Pendidikan Islam, Tinjauan teoritis dan praktis berdasarkan pendekaan Interdisipliner, Jakarta: Bumi Aksara, 2003.

Arifin M, Filsafah Pendidikan Islam, Jakarta: Bumi Aksara, 2010. Arifin M, Ilmu Pendidikan Islam, Suatu Tinjauan Teoritis dan

Praktis Berdasarkan Pendekatan Interdisipliner, Jakarta: Bumi Aksara, 2014.

Badri Yatim, Sejarah Peradaban Islam. Jakarta: Raja Grafindo Persada, 2001.

Djuawaedi M Irsjad, Pembaharuan Kembali Pendidikan Islam, Ciputat: Karsa utama mandiri dan PB mathala'ul Anwar, 1998.

Fazlur Rahman, Islam dan Modernitas:Tentang Transformasi Intelektual, Bandung: Pustaka, 1995.

Fazlur Rahman, Gelombang Perubahan Dalam Islam: Studi Tentang Fundamentalisme Islam, Jakarta: Rajawali Grafindo Persada, 2001. Fazlur Rahman, The QureAnic Solution Of Pakistan's Educational Problem 'eS, Islamic Studies, Vol. 6, No. 4, 1967.

H.A.R Tilar, Beberapa Agenda Reformasi Pendidikan Nasional Dalam Persepektif Abad 21, Magelang: Tera Indonesia, 1998.

Haryu Islamuddin, Psikologi Pendidikan, Yogyakarta: Pustaka Pelajar, 2012.

Hasan Basri, Metode Pendidikan Islam Muhammad Qutb, Kediri: Stain Kediri Press, 20.

Hasan Sulaiman Fatiyyah, Pandangan Ibnu Khaldun Tentang Ilmu dan Pendidikan, Bandung, 1987.

Helva Zuraya, Konsep Pendidikan Fazlur Rahman, STAIN Pontianak: Jurnal Khatulistiwa - Journal Of Islamic Studies, Volume 3 Nomor 2 September 2013.

Ibnu Khaldun Abdurrahman, Muqodimmah Ibnu Khaldun: Wa Hiya Muqodimmah alKitab al-Musamma Kitab al-Ibar wa Diwan al-Mubtada wa al-Khobar fi Ayam al-arb wa AL-Ajam wa al-barbar wa Man Asharahun min Dzaqwi al-Sultan al-Akbar, Beirut: Dar al-kitab al-Almiyah, 1993.

Ihsan Fuad, Dasar-dasar Kependidikan, Bandung: Rineka Cipta, 2003

Langgulung Hasan, Asas-Asas Pendidikan Islam, Jakarta: Pustaka Al-Husna, 1980.

Langulung Hasan, Beberapa pemikiran Tentang Pendidikan Islam, Bandung: Al-Ma'arif, 1980. 
Majid Abdul dan Andayani, Pendidikan Islam Berbasis Kompetensi: Konsep dan Implementasi kurikulum 2004, Bandung: Remaja Rosdakarya, 2004.

Malik Fajar, Reorientasi Pendidikan Islam, Jakarta: Fajar Dunia, 1999.

Muanrji, Ilmu Pendidikan Islam, Jakarta: PT Bina Ilmu, 2004.

Nata Abbudin, Pemikiran Para Tokoh Pendidikan Islam, Jakarta: PT. Raja Grafindo Persada, 2003.

Nata Abbudin, Filsafat Pendidikan Islam, Jakarta: Logos Wacana ilmu, 1997.

Nata Abbudin, Kapita Selekta Pendidikan Islam, Bandung: Angkasa Bandung, 2003.

Nizarr Samsul, Filsafat Pendidikan Islam: Pendekatan Historis, Teoritis dan Praktis, Jakarta: Ciputat Press, 2002.

Quthb Sayyid, Ma'allim fii AL-Thariq, Kuwait: al-Ittihad al-Islamy al-Alamiy, 1978.

Ramayulis, Filsafat Pendidikan :Telaah sistem Pendidikan dan pemikiran para tokohnya, Jakarta: Kalam Mulia, 2009.

Rizki M Fahmi, Pemikiran Fazlur Rahman Tentang Pendidikan Islam Neo-Modernis, Skripsi Universitas Muhammadiyah Surakarta, 2018.

Saihu, "Pendidikan Sosial Yang Terkandung dalam Surat At-Taubah Ayat 71-72", Edukasi Islami: Jurnal Pendidikan Islam, VOL: 09. No: 01 (2020): 127-148.

Syaiful Bahri, Strategi Belajar Mengajar, Suraka: Djamarah Rineka Ciptarta, 2013

Tafsir Ahmad, Ilmu Pendidikan Islam, Bandung: PT. Remaja Rosdakarya, 2013. Tony Buzan, Buku Pintar Mind Map, Jakarta: PT Gramedia Pustaka Utama, 2010. Undang-undang Sistem Pendidikan Nasional (UU RI No.2. Th. 1989), Jakarta: Sinar Grafika.

Wiji Suwarno, Dasar-Dasar Ilmu Pendidikan, Jogjakarta: Ar-Ruzz, Media Group. Yasin A, Fatah, Dimensi-dimensi Pendidikan Islam, UIN: Malang Press, 2008.

Zainuddin Rahman, Kekuasaan dan Negara (Pemikiran Pendidikan Politik Ibnu Khaldun). Jakarta: Gramedia Pustaka Utama, 1992. 
